\title{
SEISMIC AND IMPACT-PRESSURE MONITORING OF FLOWING AVALANCHES
}

\author{
By P. A. Schaerer and A. A. Salway \\ (Division of Building Research, National Research Council of Canada, 3904 West 4th Avenue, \\ Vancouver, British Columbia V6R $\mathrm{P}_{5}$, Canada)
}

\begin{abstract}
Continuous records have been made during the passage of dry-snow avalanches of both seismic signals, which allows the avalanche speed to be estimated, and impact pressures on load cells with surface areas of 645 and $6450 \mathrm{~mm}^{2}$. The impact-pressure recordings show an initial peak followed by a base pressure. The observed initial and base pressures vary strongly within avalanches and from one avalanche to another, but, on average, they can be correlated with the frontal speed and the density of the deposited avalanche snow. It is concluded that well-developed dry-snow avalanches have an unsteady wave motion similar to the slug flow observed in ultra-rapid flow of water, and that they consist of three stratified components: dense flowing snow at the bottom, light flowing snow, and powder snow.
\end{abstract}

RÉsumé. Auscultation des pressions sismiques et d'impact des avalanches coulantes. Des signaux sismiques permettant d'évaluer la vitesse des avalanches et les pressions d'impact exerceés sur des cellules dynamométriques d'une surface de 645 et de $6450 \mathrm{~mm}^{2}$ ont été enregistrés de façon continue durant le passage d'avalanches de neige poudreuse. Les pressions d'impact enregistrées indiquent un maximum initial suivi d'une pression normale. Les pressions initiales et normales observées varient grandement pour une même avalanche et d'une avalanche à l'autre, mais, en moyenne, il y a corrélation avec la vitesse de front et la densité de la neige déposée par l'avalanche. Les auteurs concluent que les grandes avalanches poudreuses ont un mouvement ondulatoire instable qui rappelle l'écoulement en bouchon des masses d'eau ultra-rapide. Ces avalanches comportent trois strates: une neige dense et coulante, couverte de neige légère et coulante, elle-même couverte de neige poudreuse.

Zusammenfassung. Beobachtung abgehender Lawinen mit seismischen Mitteln und Stossdruckmessungen. Während des Abganges von Trockenschneelawinen wurden seismische Signale, die eine Abschätzung der Geschwindigkeit erlaubten, und Stossdrucke auf Druckzellen mit 645 und $6450 \mathrm{~mm}^{2}$ Oberfläche laufend registriert. Die Stossdruckaufzeichnungen zeigen ein anfängliches Maximum, dem ein niedriger Druck folgt. Die beobachteten Anfangs- und Basisdrucke variieren stark innerhalb der Lawinen und von einer Lawine zur anderen, können aber im Mittel mit der Frontgeschwindigkeit und der Dichte des abgelagerten Lawinenschnees korreliert werden. Es wird gefolgert, dass gut entwickelte Trockenschneelawinen eine unregelmässige Wellenbewegung ausführen, ähnlich dem überschnellen Fluss von Wasser, und dass sie aus drei geschichteten Komponenten bestehen: dichtem, fliessendem Schnee am Grunde, leichtem Schnee und Pulverschnee.

\section{OBSERVATION SITE}

The Division of Building Research of the National Research Council of Canada has recorded avalanche impact pressures since 1971 , and also, since 1976 , seismic signals in the avalanche path, Tupper No. I, on the east side of Rogers Pass. This research has been carried out with the object of obtaining observational data concerning the behaviour of avalanches. At the Rogers Pass site the avalanches start on grassy slopes and cliffs at an elevation between $\mathrm{I} 800$ and $2300 \mathrm{~m}$, and after falling over steep rock are channelled in a $500 \mathrm{~m}$ long straight rock gully, which is about $25 \mathrm{~m}$ wide. Numerous small avalanches fill the bottom of the gully in the early part of the winter to form a base of hard-packed snow with an incline between $32^{\circ}$ and $35^{\circ}$. Artificial earth dams maintain a channel at the lower end of the gully and guide the avalanches across a snowshed over the Trans-Canada Highway.

The avalanche path, Tupper No. I, was selected because it is readily accessible from a highway and produces 20 to 30 avalanches every year, making frequent observations possible. The frequency of the avalanches, however, means that snow is continually removed in the starting zone, thus preventing the formation of very large ones. For this reason the observations are of avalanches with a narrow range of variables such as volume, flow depth, and speed. 


\section{INSTRUMENTATION}

\section{Pressure sensors}

Steel frames, on which load cells could be mounted at different heights, were placed in the centre of the avalanche track at the lower end of the rock gully, elevation I $340 \mathrm{~m}$, and on the snowshed, elevation I $220 \mathrm{~m}$. The frames, $5.2 \mathrm{~m}$ high and facing the avalanches with a $5^{\mathrm{I}} \mathrm{mm}$ wide edge of box steel, were designed for an impact pressure of $42 \mathrm{kN} / \mathrm{m}$.

The load cells presented disc-shaped surfaces of $645 \mathrm{~mm}^{2}$ and $6450 \mathrm{~mm}^{2}$ enclosed in a rigid steel housing $4 \mathrm{~mm}$ thick. In order to approximate the free-flow condition the outer cases of the cells were cylindrical and streamlined, and the loading surfaces were placed at least three times their diameter in front of the mounting frame. Between four and eight load cells were mounted in the avalanche track, the exact number depending on the number of channels available for recording.

Impact pressures, measured with Statham UL-4 load-cell accessories and Statham UC-3 transducers, were transmitted by buried armour-shielded instrument cable to an automatic recording system situated in the highway snowshed. Although the transducers produced satisfactory signals, their failure rate was high, mainly due to vibrations caused by avalanches.

Static calibration of the load cells was carried out in the field laboratory by loading each one with standard weights and recording signal levels. In a special study of their damping rate performed at the Division of Building Research it was found that the output signal fell to zero within $0.03 \mathrm{~s}$ of a single impact load.

\section{Seismic sensors}

Four Geospace GSD-20D i4 Hz vertical seismic geophones with hydrophone cases were buried about $150 \mathrm{~mm}$ deep in the ground of the avalanche gully. They were approximately $30 \mathrm{~m}$ apart down the fall-line and individually connected via cable to the recording system in the snowshed. The geophone sites were quiet and well isolated from extraneous background noise. Traffic did not present a problem, probably because the observation site was about 300 to $400 \mathrm{~m}$ up-slope from the highway. The quality of the seismic signals, however, was influenced by coupling with the ground and the depth of overlying snow, indicating that geophone locations should be carefully selected. It may be necessary to find a compromise between placing the geophones in the path of the avalanches or in positions where large quantities of snow are not expected to accumulate. Signal quality and amplitude depend upon a minimization of the filtering effects of both the snow-pack and the ground.

\section{Recording equipment}

The outputs of the load cells and the geophones were recorded on a Hewlett-Packard 3968A FM eight-channel tape recorder and several oscillographs. The recorders together with amplifiers, triggering circuitry, and a timer control were housed in boxes located at the side of the highway in the snowshed and supplied with electric power from a portable generator. The equipment has been described in some detail by Salway (1978).

\section{Triggering equipment}

Before 1977 the recording instruments were switched on for an avalanche recording by mechanical triggers containing pressure discs and microswitches rigidly attached to a steel frame up-slope of the load cells. Such devices were found to be vulnerable to damage, prone to jamming from snow and freezing rain, and liable to be buried under avalanche snow. Following the successful recording of seismic energy from avalanches during the 1976-77 season, modifications were made to enable signals from each geophone to be monitored 
continuously when avalanches were expected. Each amplified signal was converted by a true r.m.s.-to-d.c. converter and continuously compared to a threshold voltage, whose magnitude was determined from studies made during the previous season. If any one of the four geophone outputs exceeded the threshold level, the event would be recorded. Avalanches were detected successfully in this way and there were few false starts.

\section{Operational problems}

Making full-scale observations of a phenomenon as complex as a mixed snow avalanche poses problems of maintenance and operation of equipment. Although 20 to 30 avalanches occur annually at the Tupper No. I path, on average, only five avalanches per year were recorded. Of these, usually only one or two yielded observations of seismic signals and pressures for their entire duration as well as visual observations of the deposited avalanche snow.

Even when the recorders operated satisfactorily, useful signals were usually obtained from only half the load cells and three-quarters of the geophones, suggesting that the number of sensors and recording channels should be about double the specified number.

Principal failures in observations occurred when avalanches ran unexpectedly, by-passed the load cells, occurred in quick succession before the deposited snow could be inspected, or broke the signal cables. Other problems with the equipment were related to moisture, freezing rain, and vibrations.

\section{Motion of AVALANches}

\section{Ultra-rapid flow}

The motion of avalanches is very complicated and has not yet been described satisfactorily. It has become usual to employ the techniques of fluid mechanics for the solution of this problem.

In fluid mechanics the characteristics of open-channel flow are described by the Froude number:

$$
(F r)=\frac{v}{\sqrt{ }(g d)},
$$

where $v$ is the speed of the fluid, $d$ is the flow depth, measured normal to the bed, and $g$ is the acceleration due to gravity.

When the Froude number exceeds a value of about two, as in very steep channels or where the flow depth is very shallow, the flow becomes ultra-rapid and develops an unstable, wavelike surface. The limiting condition of an unstable surface may be theoretically determined by Vedernikov's criterion (Chow, I96I) which states that slug flow will form in a channel with constant cross-section at roughly $(F r)>2$. Slug flow is characterized by surges and turbulent ridges separated by highly agitated regions. At $(F r)>3.5$ the fluid becomes mixed with air, resulting in an air-entrained flow as well as an unstable surface.

Ultra-rapid flow with air-entrainment develops often on spillway faces of dams and in this connection has received attention in research and the literature. Empirical equations for the concentration of air have been developed from laboratory experiments and observations in spillways, but no adequate theory exists (Henderson, 1966).

\section{Air-entrained flow}

Mixed dry-snow avalanches are usually described in the literature as containing a dense, flowing part and a powder component, but observations made at our establishment suggest the existence of three zones, a dense flow at the bottom, a middle zone of light flow, and a 


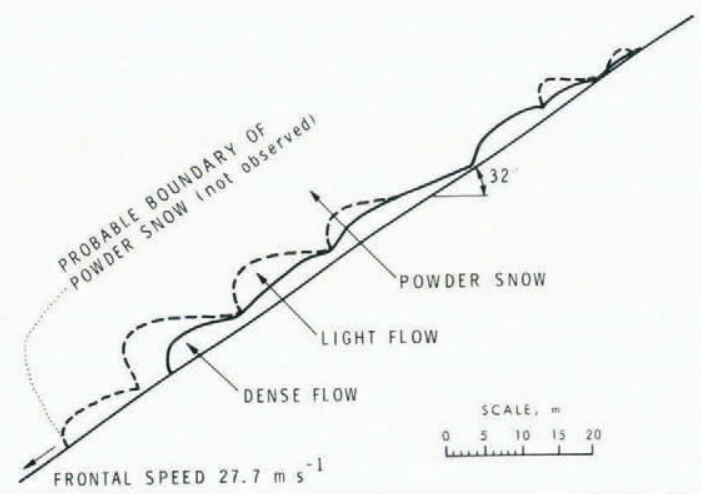

Fig. I. Profile of the avalanche Io February 1977 at the load-cell mount.

powder-snow zone (Fig. I). Similarly, three components may be observed in air-entrained water flow; a low zone of water mixed with air bubbles, an intermediate zone where large water droplets are separated from the fluid below, and an upper region of mist containing fine droplets suspended in air.

In the observed avalanches, the two lower zones were manifest as characteristic patterns of pressure signals, flow marks in the snow at the gully side, and snow packed against the load-cell mount. Only visual observations of moving avalanches indicated the existence of the powder-snow zone; none of the recorded signals could be positively associated with it, probably because the load cells and geophones were insufficiently sensitive.

The dense, flowing snow, containing the principal mass of the avalanche, was usually between 0.5 and $1.2 \mathrm{~m}$ deep. It produced impact-pressure records with an initial peak, dropping to a constant value that was sustained as long as the dense snow moved against the load cells (Fig. 2).

The middle zone of light, flowing snow is made up of powder and lumps of up to $60 \mathrm{~mm}$ in diameter, tossed upwards by turbulent motion at the surface of the dense flow.

Light flow appears on the pressure recordings as numerous individual peaks that are produced whenever a chunk of snow strikes the load cell (Figs 2 and 3). Behind the peaks the pressure drops to a level too low to be recorded adequately by the load cells.

Flow marks at the sides of the gully provided further clues to the character and depth of the light, flowing component. Surface snow was removed completely in the zone of the dense snow but was usually compacted and marked with numerous prints of snowballs from the light flow zone above.

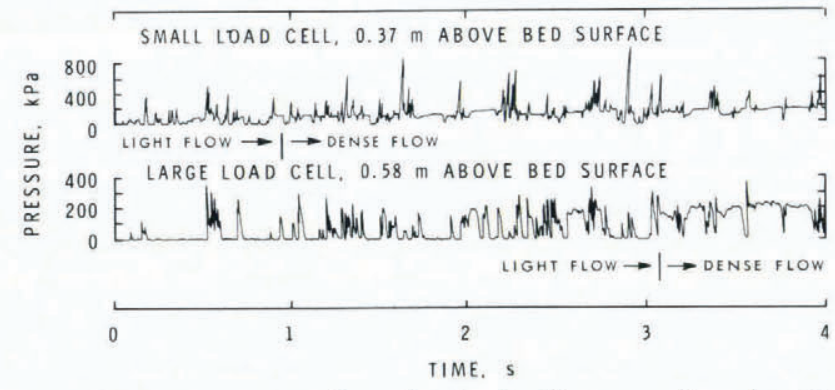

Fig. 2. Impact pressure recordings of avalanche No. 3 on Io December 1977. 


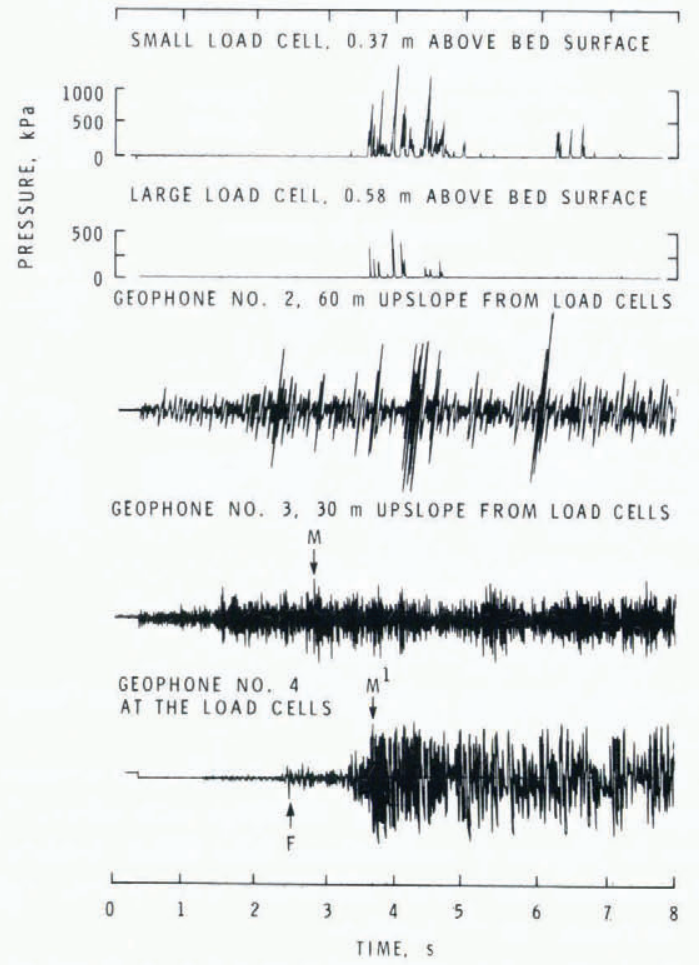

Fig. 3. Impact pressure and seismic recordings of the avalanche on 25 November 1977.

The zone of light flow must be considered a separate entity, not simply a transition between dense snow and the powder, both because of its considerable depth ( 1 to $5 \mathrm{~m}$ in the observed avalanches) and because it can separate from the dense flow. In the avalanche track there is probably a continuous exchange of mass and energy between the two zones, but in the zone of deposit the light flow frequently separates and travels a longer distance. This is often indicated at Rogers Pass by the presence of two different areas of deposited avalanche snow.

Slug flow

From observations of flow depth and measurements of the depth and density of the deposited avalanche snow it was estimated that in dry-snow avalanches the density of the light flow was about 0.1 to 0.3 times that of the dense flow. Assuming an average ratio of densities of 0.2 , an effective flow depth $d_{\mathrm{e}}$ can be defined by

$$
d_{\mathrm{e}}=d_{\mathrm{d}}+0.2 d_{1}
$$

where $d_{\mathbf{d}}$ is the flow depth of the dense snow and $d_{1}$ the flow depth of the light snow.

Substituting the frontal speed $v_{\mathrm{f}}$ for $v$ and $d_{\mathrm{e}}$ for $d$ in Equation (I), Froude numbers were obtained for the observed avalanches (Table I). Froude numbers greater than six suggest an ultra-rapid motion with slug flow and air entrainment.

When the boundary between dense and light flow and the surface of light flow, determined from the pattern of pressure signals, were plotted over the length of an avalanche, slug waves could often be recognized at regular intervals (Fig. I). Although they appear at regular intervals within any one avalanche, there is variation of wave intervals from avalanche to 
Table I. Avalanches USED FOR this StUdy*

\begin{tabular}{|c|c|c|c|c|c|c|c|c|}
\hline \multirow[b]{2}{*}{ Date } & \multirow[b]{2}{*}{$\begin{array}{c}\text { Frontal } \\
\text { speed } \\
v_{\mathrm{p}} \\
\mathrm{m} \mathrm{s}^{-1}\end{array}$} & \multicolumn{3}{|c|}{ Average flow depth } & \multirow[b]{2}{*}{$\begin{array}{c}\text { Density } \\
\text { deposit } \\
\rho_{\mathrm{s}} \\
\mathrm{kg} \mathrm{m}^{-3}\end{array}$} & \multirow{2}{*}{$\begin{array}{c}\text { Froude } \\
\text { number } \\
(F r)\end{array}$} & \multirow[b]{2}{*}{$\begin{array}{c}\text { Friction } \\
\text { coefficient } \\
\xi \\
\mathrm{m} \mathrm{s}^{-2}\end{array}$} & \multirow[b]{2}{*}{$\begin{array}{c}\text { Wave } \\
\text { internal } \\
\mathrm{s}\end{array}$} \\
\hline & & $\begin{array}{c}\text { Dense } \\
d_{\mathrm{d}} \\
\mathrm{m}\end{array}$ & $\begin{array}{c}\text { Light } \\
d_{1} \\
\mathrm{~m}\end{array}$ & $\begin{array}{c}\text { Effective } \\
d_{\mathrm{e}} \\
\mathrm{m}\end{array}$ & & & & \\
\hline \multicolumn{9}{|c|}{ Observations at snowshed } \\
\hline 20 January 1972 & 18.5 & 0.5 & 2.0 & 0.9 & 200 & 6.2 & I 780 & 0.9 \\
\hline I December 1972 & 30.1 & 1.2 & $4 \cdot 3$ & 2.1 & 420 & 6.6 & I 410 & I. 44 \\
\hline Io February 1975 & 31.4 & I.I & 4.0 & 1.9 & 310 & $7 \cdot 3$ & I 660 & none observed \\
\hline \multicolumn{9}{|c|}{ Observations in gully } \\
\hline 1o February 1977 & $27 \cdot 7$ & 1.0 & 2.0 & I.4 & 330 & $7 \cdot 5$ & I 420 & 0.69 \\
\hline 25 November 1977 & $24 \cdot 4$ & 0.7 & 1.8 & I.I & 210 & $7 \cdot 4$ & I 490 & 0.8 \\
\hline Io December I 977 & 25.5 & 0.6 & 2.5 & I.I & 250 estimated & 7.8 & I 590 & none observed \\
\hline Io December I 977 & $24 \cdot 4$ & 0.5 & 2.0 & 0.9 & 250 estimated & 8.2 & 1810 & 1.23 \\
\hline Io December I 977 & 34.8 & 0.9 & 4.0 & 1.7 & 370 & 8.5 & 1710 & 1.2 \\
\hline
\end{tabular}

* All the avalanches contained dry snow.

avalanche (Table I). No theory has yet been developed to relate these wave intervals to other characteristics of the flow.

Variations of impact pressure suggesting zones of different density were also observed in avalanche studies in Japan and the U.S.S.R. Shimizu and others (1974) recorded impact pressures similar to those in Figure 2, concluding that light, flowing snow preceded dense, flowing snow at the observation site; later (Shimizu and others, 1977), he noted pressure pulses indicating the wave nature of avalanches.

Kotlyakov and others (1977) observed high pressures at the bottom $2 \mathrm{~m}$ of avalanches, probably the dense, flowing zones, and pressures that were three to ten times lower at levels between 2 and $6 \mathrm{~m}$ from the bed surface, obviously representing the zone of light flow.

\section{Charagteristics of Seismic signals and SPeed estimation}

Seismic signals obtained so far generally contain frequencies ranging between 2 and about $30 \mathrm{~Hz}$. When the instrumentation is triggered by the upper geophones, the onset of seismic energy recorded by lower geophones often indicates the arrival of the avalanche front, for example, point F on geophone no. 4 trace (Fig. 3). Such points helped to provide the estimates for the frontal speed of the avalanches. Velocity estimates were also obtained by correlating seismic and pressure peaks (Salway, r978). Following the onset of seismic energy, the signals are either strongly pulsating (geophone no. 2, Fig. 3) or weakly pulsating (geophones nos 3 and 4). Such signals provide strong evidence of surging or slug flow within avalanches. In some cases it was possible to cross-correlate major peaks and cycles between geophone signals and hence obtain estimates of velocities within the avalanche, for example, points $\mathbf{M}$ and $\mathbf{M}^{\prime}$ (Fig. 3) suggest a velocity of $33.9 \mathrm{~m} \mathrm{~s}^{-1}$ for this phase of the avalanche travelling between geophones nos 3 and 4 .

Because the study yielded observations of the frontal speed and flow depth of the avalanches it was of interest to check present practice for calculating avalanche frontal speeds $v_{\mathrm{p}}$. The equation generally used for the solution of practical problems is

$$
v_{\mathfrak{f}}=(\xi R(\sin \psi-\mu \cos \psi))^{\frac{1}{2}}
$$

where $R$ is the hydraulic radius (for avalanches at the Tupper No. I site $R$ is assumed to be equal to the effective flow depth $d_{\mathrm{e}}$ ), $\psi$ is the incline of the avalanche track, $\xi$ is a coefficient 
of turbulent friction, and $\mu$ is a coefficient of kinetic friction (for the observed medium size avalanches, $\mu$ can be approximated by $\mu=5 / v$ (Schaerer, [1975])).

Values for $\xi$ were calculated using Equation (3) for the eight avalanches in Table I. $\psi$ was taken as $27^{\circ}$ for snowshed observations and as $32.5^{\circ}$ for observations in the gully. The range of values obtained for $\xi$ confirms earlier results (Schaerer, [1975]).

It must be stressed that the coefficient of turbulent friction $\xi$ is strongly dependent on the roughness of the avalanche track. The Tupper No. I avalanche path had a straight track with a smooth surface of previously deposited avalanche snow. The value for $\xi$ is expected to be lower for an average avalanche track with a rougher surface.

\section{IMPACT PRESSURES}

Besides continuously monitoring the flow pattern and depth of the avalanches, the load cells yielded quantitative information on avalanche impact pressures.

\section{Initial peak pressure}

A lump of snow impinging on a rigid object produces an initial peak pressure $p_{i}$ owing to its extremely rapid deceleration. The pressure on a unit surface perpendicular to the direction of avalanche flow may be expressed as

$$
p_{i}=c_{i} \rho v^{2}
$$

where $\rho$ is the density of the avalanche snow and $v$ the speed.

The coefficient $c_{1}$ is essentially dependent on the deformation of the snow, which in turn is a function of temperature, free water content, and initial density, as well as the type and bond of the snow grains.

In the dense, flowing component of avalanches an initial peak pressure appears with every new wave of dense snow. In the light, flowing component, peak pressures appear whenever a lump of snow impinges on the load cell. Because the lumps in the light flow move in random directions at speeds different from the frontal speed, there is a strong variation of impact pressures; the highest is recorded when a large lump at high velocity strikes the loading surface normally. The recordings show about one-third of the pressure peaks in the upper range (Fig. 3), and the mean of these peaks was defined as the initial peak pressure for light, flowing snow.

Table II lists mean values of $c_{1}$ for observed initial peak pressures $p_{\mathrm{i}}, v=v_{\mathrm{f}}$, and $\rho=\rho_{\mathrm{s}}$, the density of the deposited avalanche snow after the avalanche came to rest. The density of the deposited snow can be expected to be about that of the lumps of snow in motion, but owing to air entrainment the bulk density of the moving snow mass would be less.

A considerable variation of initial peak pressures and corresponding values for $c_{\mathrm{i}}$ was observed. Variations occurred not only among avalanches but also between individual waves of the same avalanche.

TABLE II. CoEFficientS OF IMPACT PRESSURE

\begin{tabular}{ccccccc} 
& \multicolumn{2}{c}{ Initial peak pressure } & & \multicolumn{2}{c}{ Base pressure } \\
\cline { 2 - 3 } \cline { 5 - 6 } & $\begin{array}{c}\text { Number of } \\
\text { observations }\end{array}$ & $\begin{array}{c}\text { Mean } \\
c_{1}\end{array}$ & & $\begin{array}{c}\text { Number of } \\
\text { observations }\end{array}$ & $\begin{array}{c}\text { Mean } \\
c_{\mathrm{b}}\end{array}$ \\
Small load cell & 8 & 1.68 & & 8 & 0.48 \\
$\quad \begin{array}{l}\text { Dense flow } \\
\text { Light flow }\end{array}$ & 7 & 1.50 & & & \\
Large load cell & 2 & 1.14 & & 4 & 0.43 \\
$\quad \begin{array}{l}\text { Dense flow } \\
\text { Light flow }\end{array}$ & 6 & 0.99 & & &
\end{tabular}




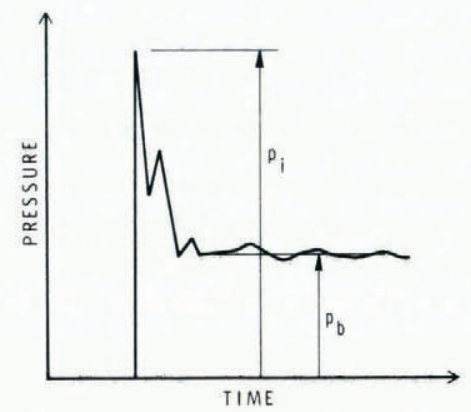

Fig. 4. Impact pressures in the dense flow.

\section{Base pressure}

After initial impact the pressure drops to a constant base pressure $p_{\mathrm{b}}$ that is maintained as long as material flows past the load cell (Fig. 4). Analogous to the initial peak pressure it was found convenient, as with the initial peak pressure, to relate the base pressure to $\rho_{\mathrm{s}}$ and $v_{\mathrm{P}}$

$$
p_{\mathrm{b}}=c_{\mathrm{b}} \rho_{\mathrm{s}} v_{\mathrm{f}}^{2} \text {. }
$$

The observed mean values for $c_{\mathrm{b}}$ are contained in Table II.

\section{Base pressure versus initial peak pressure}

The mean ratio $p_{\mathrm{i}} / p_{\mathrm{b}}$ for individual waves of dense avalanche snow was found to be 3.3 for the small load cells and 2.4 for the large load cells, results that agree well with other reported values of between two and five (Salm, 1964; Shimizu and others, 1974; Kotlyakov and others, 1977).

\section{Influence of size of load cell}

Initial peak pressure per unit area is about 1.5 times greater on the small load cell than on the large cell, but for base pressures there is little difference between the two (Table II). The variation of the initial peak pressure can be explained by the size of the snow particles in the avalanches. In those observed the diameter of the lumps of snow usually ranged between 20 and $60 \mathrm{~mm}$, enough to cover the small loading plate (diameter $28.7 \mathrm{~mm}$ ) but not the large one (diameter $90.6 \mathrm{~mm}$ ). Consequently, snow particles impinging on the large plate exert an impact force on only part of the loading surface.

\section{Conclusion}

Observations have confirmed the complex nature of a fully developed dry-snow avalanche. Its surface in motion is ill-defined, density varies with height and length of avalanche, and forward speed can be different for individual parts of the moving snow. One can imagine the effect of this phenomenon on an object in its path. A structure, for example, would be pounded by a series of waves and could fail as a result of dangerous vibrations. Such conditions are particularly wild at the interface between dense and light, flowing snow, where objects would be subjected to strong impulsive forces.

Although we have presented equations with respect to impact pressures, caution is required in applying them for the design of structures. It must be stressed that Equations (4) and (5) and the coefficients in Table II refer to averages only; yet there is a wide variation of pressure that cannot be explained satisfactorily. The maximum impact pressures could well be twice the average values. 
Much more information needs to be collected before it will be possible to predict the behaviour and the effects of large avalanches. Probably one of the greatest difficulties is the wide variation in avalanche characteristics; it will require a large number of observations to provide information about their numerous parameters.

\section{Agknowledgements}

The authors wish to thank Paul Anhorn and Edward Campbell for making the observations, often under hazardous conditions, and the Superintendent and Staff of Glacier National Park for their co-operation. This paper is a contribution from the Division of Building Research, National Research Council of Canada, and is published with the approval of the Director of the Division.

\section{REFERENCES}

Chow, V. T. 1961. Open channel flow. (In Streeter, V. L., ed. Handbook of fluid dynamics. New York, McGrawHill Book Co., Inc., p. 24-1-24-59.)

Henderson, F. M. 1966. Open channel flow. New York, Macmillan.

Kotlyakov, V. M., and others. 1977. The dynamics of avalanching in the Khibins, by V. M. Kotlyakov, B. N. Rzhevskiy, and V. A. Samoylov. Fournal of Glaciology, Vol. 19, No. 81, p. $431-39$.

Salm, B. 1964. Anlage zur Untersuchung dynamischer Wirkungen von bewegtem Schnee. Zeitschrift für angewandte Mathematik und Physik, Vol. 15, Fasc. 4, p. 357-75.

Salway, A. A. 1978. A seismic and pressure transducer system for monitoring velocities and impact pressures of snow avalanches. Arctic and Alpine Research, Vol. io, No. 4, p. 769-74.

Schaerer, P. A. [1975.] Friction coefficients and speed of flowing avalanches. [Union Géodésique et Géophysique Internationale. Association Internationale des Sciences Hydrologiques. Commission des Neiges et Glaces.] Symposium. Mécanique de la neige. Actes du colloque de Grindelwald, avril 1974, p 425-32 (IAHS-AISH Publication No. 114.)

Shimizu, H., and others. 1974. Kurobe kyōkoku kősoku nadare no kenkyū. 3 [Study on high-speed avalanches in Kurobe canyon. 3]. [By] H. Shimizu [and 5 others]. Teion-kagaku: Low Temperature Science, Ser. A, [No.] 32, p. $113-27$.

Shimizu, H., and others. 1977. Kurobe kyōkoku kōsoku nadare no kenkyū. 5 [Study on high-speed avalanches in Kurobe canyon. 5]. [By] H. Shimizu [and 5 others]. Teion-kagaku: Low Temperature Science, Ser. A, [No.] 35, p. 1 I 7-32. 